\title{
THE PUBLIC INTELECTUAL AND THE LEGITIMATION CRISIS IN THE DIGITAL ERA: FROM SOCIAL CRITICISM TO PERSONAL CONVICTIONS
}

\section{Gomilko O. Ye.}

\section{INTRODUCTION}

The attenuation of ideology in the legitimation process, called by Jürgen Habermas the legitimation crisis of late capitalism ${ }^{1}$, has been deepened by enhancing the influence of science on human lives. In the digital era, cognitive and normative pinpointing of basic values of society comes predominantly from ideology and religion, which had also been a significant factor of impact on human conscience, to science. It causes the public dimension of science to gain in strength. Despite severe criticism of science as a risk factor, it has been taking charge of human salvation by helping humans perceiving themselves as rational and peaceful beings, acknowledging the right for a decent life not only for themselves but also for other living beings. It means that science approaches the field of morality ever closer. Hence the material function of science has been losing its meaning of a priority. Science, similar to religion or ideology, becomes an important factor of a human being's conscience. The public dimension of science acquires its important embodiment in the scientist's public stance frequently called public intellectual, which is subject to considerable changes in the digital context. One of such changes is the strengthening of educational dimension, of public intellectual that is, when the public dimension becomes an educational one. Hereof the transfer and preservation of knowledge with the help of education imply protection of its moral aspects. Consequently, science, education and practice encounter one another.

Unlike left and right social criticism, which sees a means of overcoming human sufferings in social transformations, the public intellectual stance has been shifting its accents from social criticism onto developing people's convictions to change themselves. The

\footnotetext{
${ }^{1}$ Habermas J. (1992) Legitimation Crisis. Cambridge: Polity Press.
} 
historical experience provides us with evidence that could be no social transformations without morality was rejected. Ėmile Durkheim's opinion on political revolutions being bloody theatrical productions that bring about hardly any changes in social systems is borne out by history. In order to produce real social changes, political transformations are to express deep moral values and aspirations of society, for “... society is shaped not simply by multitudes of individuals that comprise it, not by land that they take up, not by things that they use, not by movements they produce; it is first and utmost shaped by the idea that it has of itself. It may well happen that it becomes hesitant about how it should comprehend itself: it is torn apart into different directions. However, once such conflicts take place, they tend to occur not between the ideal and the reality, but between different ideals - those of yesterday and those of today,"2.

The thought of primacy of moral principles of society is further elaborated by Vilfredo Pareto, who stated that since any political regime constitutes a consequence of the previous and a source of the future ones, it is possible to make a negative or positive evaluation of it only by considering all impacts upon it. Given that a number of such possibilities is infinite, "we won't be able to carry out such evaluation, instead we will be forced to refuse the absolute and address the evanescent, as well as define the concept of good and evil and research solely the nearest consequences of the political regime in question, having set the approximate limits on this nearest period"3. Instead of searching for the absolute, the social thought had better consider the analysis of the current state of society with a view to defining limits of a particular social embodiment of good and evil.

Therefore, the task of the intellectual lies in helping human beings puzzle out the conflicts of ideals, the concepts of good and evil and stimulate them to self-improvement. Then a human dream of a perfect society as complying with human being's needs stands a chance of coming true. So, a human being's self-improvement may be considered not only in personal terms, but also as an important factor

${ }^{2}$ Дюркгайм Е. (2002) Первісні форми релігійного життя: Тотемна система в Австралії. - Київ: «Юніверс», с. 394.

${ }^{3}$ Парето В. (2011) Трансформация демократии / пер. с итал. М. Юсима. М.: Издательский дом «Территория будущего», с. 29. 
in adopting an active public stance, which will chiefly aimed at needs of social life.

The public stance requires integrity of the moral virtues, whose acquisition depends in no small part on human ability to cope with "the dark side" of their nature, or in other words, with "internal demons" . It would be almost impossible to improve society without overcoming the aggressive side of human nature. One of the key task of the public intellectual is to persuade people of the need of selfimprovement basically to subdue their inner aggression and intolerance. To teach people tolerance and sympathy not only for others but for themselves assigns the importance of the public intellectual. It is no coincidence that Yuval Harari speaks of resilience as the main task of education in the $21^{\text {st }}$ century. His question is apt and to the point: "How do you live in an age of bewilderment, when the old stories have collapsed, and no new story has yet emerged to replace them" ". According to Harari, it is education that is supposed to teach this: "schools should downplay technical skills and emphasize general-purpose life skills. Most important of all will be the ability to deal with chance, learn new things, and preserve your mental balance in an unfamiliar situation. In order to keep up with the world of 2050, you will need not merely to invent new ideas and products - you will above all need to reinvent yourself again and again". For in Harari's opinion, it is not only the economy that is undergoing cardinal changes, but also the very meaning of being a human. He prognosticates that by the year of 2048 physical and cognitive structures will have dissolved in myriads of data bits. Unlike previous watersheds, when way of living and working did not require humans to change themselves, the digital revolution urges them to change their nature, as they will have to adapt to their constant need of change, at the same time remaining what they are. Such changes demand a strong mental versatility and the ability to maintain the emotional balance. To teach a human being to feel comfortable while constantly leaving the comfort zone becomes a key task of modern

${ }^{4}$ Pinker S (2011). The Bettter Angels of Our Nature. The Decline of Violence in History and its Causes. - Allen Lane.

${ }^{5}$ Harary Y. (2018) 21 Lessons for the $21^{\text {st }}$ Century - Jonathan Cape, London, p. 257.

${ }^{6}$ Ibid p. 262. 
education. As a result, the principal goal of an educational process is determined not by the complex of knowledge or acquired skills, but by the human ability to demonstrate the dynamic resistance to Being.

The digital era strengthens human's responsibility and requires to possess considerable rational skills and abilities, since there is a strong likelihood that humans will be compelled to encounter not a class enemy, but a product of their own activities -artificial intelligence and other novel technologies where the type of interaction between humans and machine will prove decisive for the future of society. Unlike the industrial type of interaction, when the machine performs functions of the human and the latter proves a mere adjunct in this process, the digital age will render both actors of the interaction indispensable. The human and the machine enable one another's actions not as supplements, but as counterparts: without human thinking, not mechanical action, the function of the machine becomes ineffective. Realization of human thinking's resources implies actualization not only of scientific rationality, but also of other rationality types. This is why an important task of the public intellectual lies in legitimation of different kind of knowledge in the public domain. To extend the rationality field means extending the zone of human dignity and freedom, thus furthering the improvement of human life. This article is dedicated to the research on the public intellectual in the digital age on the ground of rethinking a wide range of such concepts as education, rationality, human nature, publicity of the scientist, etc. The methodological base for the article is established by the social and anthropological ideas of È. Durkheim, V. Pareto, M. Weber, J. Habermas, Y. Harari and P. Sloterdijk, who provide a theoretical exit of social analysis from the realm of the economic and political into that of the moral as a precondition of the transformation of the anthropological.

\section{Democratic legitimations as "domestication" of "black swans"}

Educational legitimations and university autonomy. The possibility of the scientist to enter the public domain depends on the extent to which the principle of university autonomy is preserved, which guarantees the independence of its thinking. However, violent attacks on rationality lead to destruction of this principle. Distrust of science becomes a mood of the general majority. Of the threats posed 
by such distrust warns the recently released NBO series "Chernobyl", which, according to the IMDB version, within a short period of time managed to get the title of the most popular series of all time, having outperformed the cult-favourite "Game of Thrones". In the midst of arguably the most dramatic nuclear catastrophe that took place in 1986 in Ukraine, the series demonstrates what happens to those who don't take heed of the voice of science and reason. Hence, the appeal of the series' producers to people for being careful and not neglecting rationality has received feedback. However, the question remains the same - has the appeal been understood? For the intellectual's public voice to provoke thought within a society, it has to acknowledge university autonomy as a basic premise for strengthening reason. For autonomy of reason and the principle of university autonomy are closely related entities enabling scientific research on the one hand, and the public activity of the scientist on the other.

The connection between university and its public mission is attested to by the establishment of the former. It is the autonomy of the medieval university that legitimizes it as a cultural institution that strives for independence from the Church, town or monarch in order to enable a dialogue between them. As we can see, the public function of university is of much importance, the foundation of which was laid at its roots, as the then "game of thrones" commences heeding rules thanks to the emergence of the university. Fury of medieval cruelty pales in comparison with the tricks played by political reason with democracy acting as its accomplice. For it is democracy that paves way for a dialogue within the search of consensus among multiplicity of opinions and viewpoints. The process of producing and acquiring knowledge is not possible without this process. Not for nothing was it exactly the medieval university that legitimized the value of democracy in society. Interestingly, the symbols of bloody civil slaughter in medieval England, that of the red and the white rose, are still used in English universities, though in peaceful terms and mainly in political or sports contests.

Therefore, teaching people to live peacefully in a climate of competition based on understanding and tolerance determines the public mission of the university. Standing in contrast to Plato's Academy or Aristotle's Lyceum, whose activities were caused to a significant extent by the crisis of the ancient polis, the medieval 
university emerges in the midst of the European civilization's fight for survival. Cultural achievements of the latter were finding themselves on the brink of extinction under the pressure of the fury of barbarian peoples. Establishment of the first universities in the 11-century Europe led to mobilization of the efforts made by the European civilization, which helped it withstand barbarian onslaught. This was possible thanks to the European civilization rediscovering the power of human mind aimed at stemming the tide of the human fury. That is why the Sorbonne Joint Declaration ${ }^{7}$ states that cultural, social and technical dimensions of the European Continent were to a great degree determined by its universities, which keep playing a crucial role in their development to this day.

The illusion of peace and threats of barbarism. The current circumstances beget threats to European culture. Unlike early medieval times, the nowday's Western world is sucked back into the vortex of barbarism not by famine or aggression, but by welfare and tranquility. The digital age against the backdrop of the post-war peace creates an illusion of irreversible progress of civilization. The Western world loses its vigilance and weakens its protection. It is with regret that we are witnessing the important value-based and institutional achievements of the Western world devaluing. Brexit in Great Britain, presidential race in the USA and Ukraine are cases in point. The decline of the European civilization turns from a theoretical assumption into a hard fact. It seems bewildering that citizens of Great Britain, the country that had laid foundation of democracy and of Europe's modern unity, have now set out to destroy it.

A wide range of facts attest to a negligent attitude of citizens towards the existing institutes and values of the Western world, making one contemplate the reasons for such civilizational turnabout. Popularity and strong support of populists and non-system politicians in those countries where universities set world-class standards contradicts the well accepted deliberations that we resort to while analyzing Ukrainian realities. For the source of all the trouble is the absence of political culture among our fellow citizens as well as lack of developed social institutions, high-quality education and

${ }^{7}$ Sorbonne Joint Declaration. Joint declaration on harmonization of architecture of European higher education system. URL: http://euroosvita.net/prog/data/attach/ 1037/sorbonne_declaration.pdf 
democratic experience, i.e. all those things that Britain and the USA proud themselves on. However, the experience of those countries signifies that even a high level of democratization of society and education are not capable of withstanding the pressure of the archaic, which results in weaker positions of human mind. The calls to ruin the existent authorities made by some Ukrainian politicians fit perfectly in with the logic of barbarism. However, they are not unique in their aspirations. Unfortunately, the Western culture is not as threatened by terrorism or refugees as by political populism eradicating its foundation, i.e. its rational institutionalism.

Black Swans on the democratic horizon. The economist, Nassim Taleb, calls unpredicted events in the world Black Swans ${ }^{8}$. The progress of the Western civilization towards more feeble European values can be considered as emergence of such Black Swans, since mankind is at a loss in front of their challenges and has proven unable to put up any resistance. This is why N. Taleb speaks of the limited ability of modern science and rational thinking in general to cope with Black Swans. He claims that "contrary to social-science wisdom, almost no discovery, no technologies of note, came from design and planning-they were just Black Swans... The strategy is, then, to thinker as much as possible and try to collect as many Black Swan opportunities as you can".

We are made to not see Black Swans, according to N. Taleb, by the Platonic fold what is "the explosive boundary where the Platonic mind-set enters in contact with messy reality, where the gap between what you know and what you think you know becomes dangerously wide. It is here that the Black Swan is produced" 10 . To debunk this fold is a task to be completed by the public intellectual. By drawing attention to the unpredictable and accidental in human's lives, the intellectual is to teach people to recognize random events and not to fear them. It is remarkable that the Platonic fold was criticized hundreds of years ago by Aristotle. Just as N. Taleb, Aristotle called upon researchers to consider not speculative constructions of thinking, but rather concrete individuals who combine in themselves both their

${ }^{8}$ Talleb N. N. (2008) The Black Swan. The Impact of the Highly Improbable Penguin Books.

\footnotetext{
${ }^{9}$ Ibid p. xxi.

${ }^{10}$ Ibid p. Xxv.
} 
own image and its substantive substrate. This means that multiple occurrences of the real world hold more interest for Aristotle than ideas per se. Only through connection to practice can they be discerned.

In light of research optics aimed at practice, the university emerges not only as a pillar of the autonomy of mind, but as its guide in life. The task of the university lies then in not only producing, accumulating and imparting knowledge, but also in providing a "road map" for its practical realization. For this purpose the university is to orientate itself in local environment. With a growing number of Black Swans this task takes on difficulty, as traditional analysis methods fail to "spot" them. Obviously, we are dealing here with a need to extend and diversify the spheres of the influence of mind. As a result, a rethinking of these phenomena is taking place, which are traditionally thought of as the opposite of mind. For instance, the phenomena of the realm of senses that finds its metaphorical expression in the concept of heart, or that of the world of other living creatures or machines. This is yet not about their submitting to mind, which the traditional modern philosophy is based on. Unlike the latter, the nowadays thinking strives not to exalt mind by counterposing it to other realms of life, but rather to reveal its affinity with them. Hence, we may arrive at a conclusion that it is exactly in the context of university autonomy that the transformation from Black Swans into white ones is possible, or in other words, when the unexpected and spontaneous becomes recognized and projected. So, university autonomy does not keep the scientist out of the practice of life. Quite the reverse, it facilitates saturation with reason. Thus, we are witnessing the borders of the practice of life being changed by virtue of educational legitimations of not solely marginal cultural factors but also of non-human ones (like animals and machines).

Democratic legitimations, which the university is capable of completing, enables extension of boundaries of rationality at the expense of acknowledgement of those types of knowledge that have traditionally been overlooked by it. This extension and diversification of knowledge requires procedures of its coordination and reaching the consensus. Consequently, the mind and heart have to come to terms on the ground of rationality, contributing to improvement of human life. It is evident that this process 
undermines the monopoly of that type of knowledge that is determined by the modern paradigm of science. Along with scientific knowledge, the right for rational acknowledgement should also be gained by other types of knowledge, for example, by routine and practical, personal, local, implicit knowledge, self-knowledge, etc. The scientist is thus faced with a task to not only produce scientific knowledge, but also to fulfill legitimation of the knowledge that does not fall into category of the scientific. It is crucial that this knowledge be legitimized in the public realm by scientists, as by doing so they will not find themselves counterposed to mind. Quite the opposite, they will strengthen their own foothold in culture. The fact that Black Swans hide in these types of knowledge makes legitimation even more topical.

Access to knowledge as a public value. The sphere of the intellectuals' public mission should also entail the process of improving the level of access to knowledge. Here we are talking about the acquisition of knowledge turning into the need of a wider circle of people throughout their lives. Social, technical, physical restrictions and restrictions on age have to be overcome not only by introduction of normative regulation, but also by enhancing those existential and motivational factors that trigger people to learn and change themselves. Such changes prove necessary in eliminating various prejudices, fallacies, stereotypes, mental clichés, habits, likes, skills, etc. Thanks to these changes people acquire new cognitive knacks.

\section{The publicity of intellectuals in the context of Max Weber's idea of rational legitimation}

Research of the intellectuals' public stance in the context of educational legitimations is aimed at those methods of analysis that take into consideration the phenomenon's ontological dualism: its eidetic and objective realms. The former implies speculative and constructivist experience of thinking, with the latter updating its practical and empirical component. The key concepts of the research, i.e. modernity, rationality, legitimation, are used here within the paradigm of the methodological potential of Max Weber's understanding sociology. The theoretical advantage of this methodology lies in the fact that the analysis of society and its 
institutes is determined by ways of interrelationship between social actions of separate individuals. The focus of Max Weber's theory of social rationalization is placed on these very individuals. It is no coincidence that he thought sociology as the science of human spirit that considers the social action, and in doing so aspires to provide reason-based explanation thereof - both in its flow and its influences. The main idea of sociology is defined by M. Weber as substantiation of rational behaviour manifesting itself in all spheres of human relations. It will be recalled that the social action in Weber's point of view was a sort of human action (regardless of its internal or external character) that in the sense predicted by the protagonist or the protagonists correlates with action of other people or is aimed at it. It is important to note that this action does not imply a primitive adjustment to circumstances (pragmatism is often rebuked for this trait), but a process conditioned by sense. This is why from the perspective of the social action, the motivation of an acting subject as well as orientation on a past, present and hoped-for behaviour of other acting subjects takes on principal meaning.

Thus, by researching educational legitimations, we are supposed to prognosticate the change (brought about by us) in the sense of social actions and its impact on society and its institutions. The ideally typical models of the individual proposed by M. Weber, namely the goal-rational (based on conscious choice and calculation), value-based and national (connected to planned orientation on conviction, obligations, faith), affective (as reaction to sudden, unusual acts) and traditional (as system of automatic reactions to usual irritants that are prevalent throughout daily behaviour) provide a possibility to rationally diversify the practical implementation of democratic legitimations in society. According to M. Weber, "understanding" of faith is based on the premise of an individual existing together with other individuals in the coordinate system of particular values and is designed to form the basis of social interactions in the living world. He wrote that "As in any other process, in human behaviour (Verhalten), both "external" and "internal", we can observe certain links and regularity. However, it is only in human behaviour that such links and such regularity, at least to some degree, are inherent, which can be easily explained. The "understanding" of human behaviour that we acquire through interpretation contains specific high-quality 
"obviousness", which is quite different depending on the degree of its manifestation" ".

Therefore, "understanding" of actions does not only elucidate the latter, but also enhances its rationality. For when we comprehend actions we are able to correctly react to them with the help of our own ones, even if these actions are not rational in their own right. Being aware of such model requires a conceptually other reaction to it. In this case, the social norms of interaction firmly established by the modern society prove ineffective. Rationality as a distinctive feature of people's interaction (and not as a property or strategy of individual behaviour) in this context demands corrections and wider influence. However, it should be well noted that rationality equated with explanation and understanding expresses protagonists' semantic openness towards one another. Hence, from the perspective of the understanding sociology it emerges as a driver of the worldwide historical process.

A stronger rationality implies legitimation (the procedure of establishing legality) of those values and norms of social action that are recognized by society or the majority of its members on grounds of comprehensive actual notion of them as of desirable ones. The rational legitimation is based on acknowledgement of legality of the established order and legal prerequisites for execution of power. It has its own "social structure" in the form of rational and bureaucratic management. Nevertheless, along with rational legitimation there exists a traditional legitimation grounded in belief in sanctity and immunity of traditions and authorities formed in this society. It also has a certain "social structure" in the form of class, corporate or clan management. There also comes to pass a charismatic legitimation based on acknowledgement of the exceptional features of a personality or customs and modes related to this personality. The charismatic legitimation possesses a variable "social structure" (depending on the context).

Accordingly, the task of the intellectuals' public activities in the context of university autonomy lies in legitimation of those present legitimation types that favour strengthening of desired values and norms of social actions. Then $M$. Weber's idea about the main

${ }^{11}$ Вебер М. (1998) Соціологія. Загально-історичні аналізи. Політика / Пер. 3 німецької О. Погорілого. Київ : Основи, с. 104. 
tendency of social development being its rationalization and intellectualization takes on the meaning of legitimation of legitimations, i.e. trust or distrust of a certain legitimation type is supposed to find its justification in the intellectuals' stance, upon which much importance is placed. For instance, the granting of Tomos of autocephaly to the Orthodox Church of Ukraine (OCU) did not solely belong to the realm of the Church. The whole country was witnessing Ukrainian scientists coming out into the public domain with a view to rationally justifying this event. Along with religious figures, scientific experts were receiving the Tomos of autocephaly for the OCU not at the Phanar, but in the conscience of Ukrainian citizens. Thus, accolades bestowed upon Ukrainian scholars of religion and philosophers from Metropolitan Epiphanius ${ }^{12}$ are emblematic of unity of efforts made by scientists and religious figures to secure the public recognition of the latter, and not the equivalence between their world views or ideological viewpoints. It is obvious that the common stance of scientists and religious figures in a bid for the Tomos strengthens the positions of reason in the cause of trust, which triggers actualization of mechanisms of increase in proportion of purposeful and rational actions in society.

Now the question arises as to whether the scientist is authorized to conduct legitimations in the public domain, since granting functions of legitimations depends on powers of authority. In that case university autonomy means independence from authority. This is why educational legitimations are mainly of advocative, not of binding character. So, the task of educational legitimations is to develop convictions of accuracy of one value-based choice or another. Justification of the fact that democracy is right requires arguments in support of this value-based program. The public task of intellectuals is to provide society with such arguments. For example, despite the European choice declared by their country, the vast majority of Ukrainians do not share liberal and democratic values. Quite the reverse, 73 percent of Ukrainian citizens are prone to the left ideology or authoritarianism. These unexpected data have been revealed in a

12 Митрополит епіфаній відзначив українських релігієзнавців і філософів. URL: https://www.pomisna.info/uk/vsi-novyny/mytropolyt-epifanij-vidznachyv-ukra yinskyh-religiyeznavtsiv-i-filosofiv/ 
survey conducted by VoxUkraine ${ }^{13}$. It has transpired that the majority of Ukrainians believe that it is not the personal freedom or initiative that is supposed to exert a strong influence both on economy and freedom of people, but the state. The survey has also found that the vast majority of Ukrainian politicians stick to similar rhetoric. One of the survey's authors, Tymofiy Bryk, sums up the shocking results of the survey: it emerges that Ukrainians are up for prohibition of effectively anything. Therefore, freedom has not become Ukrainians' religion. This is why populist parties and ideas enjoy so much support. Apparently, this result is driven by weak public activities of Ukrainian intellectuals in the field of advocacy and legitimation of European values.

Intellectuals' advocacy efforts are aimed at rational and consistent articulation of European values, so that behaviour of Ukrainian citizens is legitimized by these norms and values and not by the obsolete Soviet or post-Soviet traditions. Accordingly, educational legitimations imply not only justification of values and democracy norms, but also determination of ways of their transformation into senses of social action. Thus, the task of university lies also in developing indicators of practical realization of certain values and norms in society.

\section{J. Habermas' idea of reconstructive legitimation}

The legitimation process implies the necessity to agree upon different normative and value-based instructions that demand public consensus and dialogue. An effective tool of practical realization of M. Weber's idea of rational legitimation is a communicative theory of legitimation proposed by J. Habermas. In his opinion, the ideally typical legitimation models, suggested by $M$. Weber, may coexist without expressing the value-based historical genesis. This is why the problem of legitimation lies in revealing its core grounds that enables the development of desirable motivation for action for this political regime.

J. Habermas speaks of empirical and normative concepts of legitimation. However, their application, according to Habermas, will

$1373 \%$ українців схильні до лівої ідеології та авторитаризму - опитування voxukraine. URL: https://tyzhden.ua/news/230990 
be confronted by two problems: that of abstraction from systematic influence of reasons of significance (in reference to the empirical concept) and that of the influence exerted by the metaphysical context (in reference to the normativistic concept). J. Habermas suggests the third legitimation concept, which he calls reconstructive ${ }^{14}$. This concept matches the educational legitimations in the most appropriate manner. For the reconstruction, if J. Habermas is to be believed, lies first and foremost in "finding the system of justification that will enable assess data of legitimation as reliable or unreliable in (the system) $S$. "The reliable in $S$ " should only mean that anyone who defines $S$, that is, the myth, cosmology or political theory, has also to acknowledge the mentioned reasons for the legitimation validity. This coercion manifests the consistency of correlation, which follows from internal relations of the system of justification. If we drive the reconstruction to these limits, that means we have interpreted the belief in legitimation and transformed (this belief) into its consistency" "15. Thus, J. Habermas defines the main question of practical philosophy as "the questions about procedures and prerequisites whereby justifications may gain force that will come to an agreement" ${ }^{\prime \prime}$. In view of this, he sees the task of philosophical ethics and political theory in "cracking open the customary core of the universal conscience and reconstructing it as a normative concept of the customary" "17 in order to identify criteria and reasons for this core.

The idea of J. Habermas' reconstructive legitimation for the research on the intellectuals' publicity is productive in view of its accentuating the tendency of strengthening university functions of legitimation in the modern era. It is worth reminding that J. Habermas defines legitimacy as "dignity of recognizing a political order" 18 . He goes on to stress on legitimacy being "contentious demand of significance, on which (also) depends (at least) actual recognition of the stability of the prevailing order" ${ }^{\text {"19 }}$. Consequently, when

14 Габермас Ю. (2014) До реконструкції історичного матеріалізму / Пер. 3 нім. В. Купліна. Київ : Дух і Літера, с. 268.

${ }^{15}$ Ibid p. 269.

${ }^{16}$ Ibid .

${ }^{17}$ Ibid p. 267.

${ }^{18}$ Ibid p. 243.

19 Ibid. 
legitimacy of the prevailing order is undermined, we are faced with problems of legitimation. For Ukrainian state the liberal and democratic legitimations are still posing a problem, as despite the fact that liberal democracy has seemingly taken over the world, Black Swans keep obscuring its key advantage, the idea of freedom, with ever increasing frequency. This occurrence takes place not only in Ukraine.

J. Habermas defines the democratic order of society as "selfcontrolling learning process $"$ " 20 . Hence, "the democratization cannot mean some a priori preference for some organizational type, for instance, for the organizational type of the so-called comparative democracy "21. Unlike the premodern state that does not enjoy a possibility to freely control mechanisms of social integration, the modern state singles out a subsystem from its sphere of sovereign rule, which is to act as a substitution (at least partially) of system integration conducted over the values and norms of social integration. As J. Habermas points out, today core grounds are no longer legitimized. To his mind, those who approve them get straight into the medieval times, since "the power of legitimation belongs nowadays only to rules and prerequisites for communication, which provide an opportunity to distinguish between the agreement or deal reached by the free and equal from the contingent or forced consent, 22 .

This is why the normative power of the actual is not a chimera for J. Habermas. It takes on the role of an indicator of "many norms being executed against the will of those who abide by them. Before norms of rule over masses of population are unfoundedly adopted, the communicational structure, where until today the motives for our actions are formed, would have to be completely demolished"23. Hence, unlike the premodern state, which places the reasons for legitimation in the foreground, e.g. religious dogma, the modern state is focused on procedures of agreeing upon reasons for legitimation and strengthening of their normative power. The fact that the bourgeois state, according to J. Habermas, could not rely even on the integrational power of national conscience and was attempting to

\footnotetext{
${ }^{20}$ Ibid p. 250.

${ }^{21}$ Ibid.

22 Ibid p. 252.

23 Ibid.
} 
settle conflicts built in the economic system by including them into the institutional fight for distribution of power determined success of that form of the modern state that is represented by people's democracy.

J. Habermas' outlining of the theme-based rubrication of legitimation layers helps discern the intellectual's unique role in the public discourse, as different legitimation types may last for quite a long time in society. Therefore, the important task of society lies in preventing the transformation of the rest of obsolete legitimations into the hindrance to freedom. This is particularly true for Ukraine, where processes of modernization have not completely taken place. The aforementioned survey carried out by VoxUkraine that had revealed a significant prevalence of left and authoritative views among Ukrainians attests to a profound influence wielded upon the Ukrainian society by those legitimation layers that contradict the European choice made by the country.

J. Habermas singles out five complexes of problems related to legitimacy. Two of them reflect institutionalization of a new level of justification, with the remaining three reflecting the structure of the modern state. The first rubric is secularization, which heralds separation of legitimation of state power from religion. In public space of university the latter should be present only as a research object and practice of tolerance. Otherwise it is transformed into a threat to university autonomy. The second rubric is the right of reason. Its main task is to develop the procedure type of legitimation. J. Habermas goes on to speak of the abstract right and capitalist movement of goods. At issue is the discussion on 1) historical price required by the bourgeois ideals; 2) human rights; 3) limits of rationality as well as 3) consequences of "banalization" of the Enlightenment. According to J. Habermas, the fourth theme-based rubric of legitimation of the modern state is sovereignty.

The transition to a people's sovereignty implies combination of external sovereignty with political democracy. This process causes the sovereign state to emerge as a manifestation of a new legitimacy principle and rule of the third stratum at the same time, as well as a manifestation of national identity. The list is completed by the rubric of a nation. The question of national identity in the phenomenon of nationalism reveals not so much the subject of legitimation as its 
conflicts. Thus, the process of educational legitimations can be considered through the lens of these rubrics so as to understand characteristics of legitimation conflicts in the modern state. Therefore, we are able to state that it is thanks to educational legitimations that the intellectual's public activity proves an effective tool of testing (establishing and justifying) rules and prerequisites for communication, which enable the agreement between the free and the equal as well as constitute a means of undermining the old forms of communication that nourish the motivation for authoritarian action.

\section{CONCLUSIONS}

In the context of a distinctive impact of the postmodern distrust of metanarratives, which is especially true for the liberal democracy, the idea of the scientists' responsibility before society is becoming ever more relevant. In these days of post-truth that can be regarded as a pinnacle of this distrust, the strengthening of intellectuals' responsibility before society is of utmost importance. Ralf Dahrendorf's statement about the societies, in which intellectuals remain silent, being deprived of the future ${ }^{24}$ is borne out by history. In his opinion, intellectuals have the right to back one or another position, but they can act unanimously as regards approving a single position. The obligation of intellectuals is to publicly express the existent viewpoints, thus legitimating them in society. R. Dahrendorf reminds of the contract between ideas and practical actions proclaimed by the Enlightenment that, in his opinion, has not outlived its usefulness as a driving force for freedom to this day. Persuading people to not possess truth but to perceive it as "singular", i.e. as such that takes on meaning in certain context and requires its theoretical and practical substantiation, emerges as a principal task of the modern intellectual.

The intellectuals responsible before society should be driven by not only the logic of scientific analysis but to no lesser extent by the ethics of scientific research and moral consequences of cognition. According to R. Dahrendorf, it is the exit of the science into the realm of morality that enables the retention of science in the dimension of

24 Дарендорф Р. Гражданская ответственность интеллектуалов: против нового страха перед просвещением. URL: http://www.polisportal.ru/index.php? page_id=51\&id=121 
usual life. Normally, a scientist who works outside the boundaries of science and within the sphere of society is called intellectual. Hence, any scientist can become an intellectual regardless of whether he or she is humanitarian or physical scientist.

However, conducting a scientific research requires a certain institutional organization and a place to make it happen freely. University autonomy emerges as a necessary condition and principle for providing not only space for scientific activities, but also time required for this purpose. Sadly, the institutional organization of scientific activities of a Ukrainian scientist is more often than not burdened by bureaucratic requirements that ignore the expenditure of academic time on meeting them. Stepping out of academic boundaries into the realm of publicity also means for a scientist additional time expenditures, which have to be included in his or her academic time.

For the intellectual's activities to acquire the "general importance" they have to express some social interests. Above all things the intellectual is supposed to express the interests of those people who are not able or willing to do it themselves. To accomplish such a task is a high moral obligation of the intellectual. It has to take place in accordance with certain rules and in a transparent fashion.

J. Habermas' idea of communicative philosophy is foundational for the definition of the representative basis of the intellectual's public domain. According to J. Habermas, communicative is an action focused on understanding actions of separate people in the real world. It is counterposed to strategic actions in systems that are aimed at achieving success. For the communicative action is intended to reach understanding and social consensus and not to meet self-serving interests. It is the free discourse that makes the development of new norms in society possible. Apparently, the role of the intellectuals in the process is quite significant, since thanks to their public position it is possible to: 1 ) extend the representative base of the participants of communicative discourse; 2) articulate and rationally explain it; 3) establish new societal norms; 4) achieve a societal consensus on grounds of rational argumentation. Development of national sovereignty is understood by $\mathbf{J}$. Habermas as a rational process implying creation of the public will, which would reveal its anarchic nature if placed outside the boundaries of the rational procedure. Thus, 
the end goal of the communication within society is the strengthening of the state, its institutions and social interaction.

An important concept of the driving force of the intellectual's public activities is that of a vocation, which was thoroughly elaborated by Max Weber ${ }^{25}$. This concept enables the moral unity of a human being, when ethics of conviction and ethics of responsibility converge. Hence, the conviction and responsibility of the scientist are fundamental drivers of his or her public activities. This is why the scientists' preparation has to predict the formation of their ethos with the question of responsibility playing the key role.

It is important to note that apart from the ethical element of scientists' preparation as of intellectuals, the practice of developing their public skills is also supposed to be presented, e.g. the skill in holding a discussion, delivering speeches in public, providing reasons and convincing large audiences. Unfortunately, educational institutions in Ukraine, in particular universities, offer such education not actively enough. Let's say, lack of practice in holding debates, which is an integral part of the Western education starting from school, considerably decreases the public potential of the Ukrainian scientist. For this reason, one of the focus areas of the preparation of Ukrainian intellectuals may lie in a wide introduction of the institute of debates into the educational process. Apparently, the role of such an educational institution as university in this process can hardly be overestimated. University could at least come up with an initiative to hold such debates both within university and in cooperation with others. Obviously, in order to win debates it is advisable that both those participating in them and those watching them learn many things first. Accordingly, educational programs are to take into account the need of developing the scientist's public competence and, in particular, to implement a wide range of courses - rhetoric, logic, philosophy, etc. Recent presidential race in Ukraine has demonstrated a deplorable level of debate culture both among politicians and citizens of Ukraine. To improve the Ukrainians' political culture is one of the important tasks of modern Ukrainian intellectuals who, on the one hand, will gain such trust from society, and on the other, will feel the higher level of responsibility for it.

25 Вебер М. Покликання до політики. URL: http://litopys.org.ua/weber/ wbs08.htm 


\section{SUMMARY}

The paper is dedicated to research on public intellectual in the context of the legitimation crisis and technological revolution. It is maintained that the public activity of the scientist in the digital era has to focus on self-improvement of a human being. Without overcoming the aggressive human nature it would be barely possible to create a just society. One of the key tasks of public intellectual is to convince people of the need of self-improvement, which will enhance their tolerance and empathy. The digital age strengthens the responsibility of human beings and requires from them complex rational skills and abilities, as in all likelihood they will have to face not class enemies, but the products of their activity, i.e. the artificial intelligence and other new technologies. The type of interaction between humans and machines will decide the future of society. Realization of resources of human thinking implies actualization of not only scientific activity but also of other types and forms of rationality. Here is why the public task of the modern scientist is to legitimize them in the public domain. To extend the field of rationality means extending the area of human freedom. This will accordingly imply encouraging self-improvement of human life. The publicity of the scientist in the today's context means not so leaving the boundaries of academic walls as the formation of a new public dimension within their limits. At issue is the strengthening of the public dimension of education and science as crucial factors in legitimation of the values of the modern nation state. The university plays an especially important role in this process.

\section{REFERENCES}

1.Habermas J. (1992) Legitimation Crisis. Cambridge: Polity Press.

2. Дюркгайм Е. (2002) Первісні форми релігійного життя: Тотемна система в Австралії. - Київ: «Юніверс», с. 394.

3. Парето В. (2011) Трансформация демократии / пер. с итал. М. Юсима. М.: Издательский дом «Территория будущего», с. 29.
4. Harary
$\mathrm{Y}$.
(2018)
21
Lessons for the $21^{\text {st }}$
Century Jonathan Cape, London, p. 257.

5. Harary Y. (2018) 21 Lessons for the $21^{\text {st }}$ Century Jonathan Cape, London, p. 262. 
6. Sorbonne Joint Declaration. Joint declaration on harmonization of architecture of European higher education system. URL: http://euroosvita.net/prog/data/attach/1037/sorbonne_declaration.pdf

7. Talleb N. N. (2008) The Black Swan. The Impact of the Highly Improbable - Penguin Books, p. xxi.

8. Talleb N. N. (2008) The Black Swan. The Impact of the Highly Improbable - Penguin Books, p. xxv.

9. Вебер М. (1998) Соціологія. Загально-історичні аналізи. Політика / Пер. з німецької О. Погорілого. Київ : Основи, с. 104.

10.Митрополит Епіфаній відзначив українських релігієзнавців і філософів. URL: https://www.pomisna.info/uk/vsinovyny/mytropolyt-epifanij-vidznachyv-ukrayinskyh-religiyeznavtsivi-filosofiv/

11.73\% українців схильні до лівої ідеології та авторитаризму опитування VoxUkraine. URL: https://tyzhden.ua/News/230990

12.Габермас Ю. (2014) До реконструкції історичного матеріалізму / Пер. $з$ нім. В. Купліна. Київ : Дух і Літера, с. 268.

13.Габермас Ю. (2014) До реконструкції історичного матеріалізму / Пер. з нім. В. Купліна. Київ : Дух і Літера, с. 269.

14.Габермас Ю. (2014) До реконструкції історичного матеріалізму / Пер. з нім. В. Купліна. Київ : Дух і Літера, с. 269.

15.Габермас Ю. (2014) До реконструкції історичного матеріалізму / Пер. 3 нім. В. Купліна. Київ : Дух і Літера, с. 267.

16.Габермас Ю. (2014) До реконструкції історичного матеріалізму / Пер. з нім. В. Купліна. Київ : Дух і Літера, с. 243.

17.Габермас Ю. (2014) До реконструкції історичного матеріалізму / Пер. 3 нім. В. Купліна. Київ : Дух і Літера, с. 243.

18.Габермас Ю. (2014) До реконструкції історичного матеріалізму / Пер. 3 нім. В. Купліна. Київ : Дух і Літера, с. 250.

19.Габермас Ю. (2014) До реконструкції історичного матеріалізму / Пер. $з$ нім. В. Купліна. Київ : Дух і Літера, с. 250.

20.Габермас Ю. (2014) До реконструкції історичного матеріалізму / Пер. 3 нім. В. Купліна. Київ : Дух і Літера, с. 252.

21.Габермас Ю. (2014) До реконструкції історичного матеріалізму / Пер. з нім. В. Купліна. Київ : Дух і Літера, с. 252.

22.Габермас Ю. (2014) До реконструкції історичного матеріалізму / Пер. $з$ нім. В. Купліна. Київ : Дух і Літера, с. 255. 
23.Дарендорф Р. Гражданская ответственность интеллектуалов: против нового страха перед просвещением. URL: http://www.polisportal.ru/index.php?page_id=51\&amp;id=121

24.Вебер M. Покликання до політики. URL: : http://litopys.org.ua/weber/wbs08.htm

\section{Information about the author: \\ Gomilko O. Ye.,}

Doctor of Philosophy, Professor Leading Research Fellow, Department of Philosophy of Culture, Ethics, Aesthetics,

H. Skovoroda Institute of Philosophy, National Academy of Sciences of Ukraine 4, Tryokhsviatitelska str., Kyiv, 01001, Ukraine 